\title{
Improving the production and utilization of sorghum and pearl millet as livestock feed: progress towards dual-purpose genotypes
}

\author{
M. Blümmel ${ }^{\mathrm{a}, *}$, E. Zerbini ${ }^{\mathrm{b}}$, B.V.S. Reddy ${ }^{\mathrm{c}}$, C.T. $\operatorname{Hash}^{\mathrm{c}}$, F. Bidinger ${ }^{\mathrm{c}}$, A.A. Khan ${ }^{\mathrm{a}}$ \\ anternational Livestock Research Institute (ILRI), South Asia Project, Patancheru 502324, Andhra Pradesh, India \\ ${ }^{\mathrm{b}}$ Cargill Animal Nutrition European Laboratory, Spessa, Italy \\ ${ }^{\mathrm{c}}$ International Crop Research Institute for the Semi-Arid Tropics (ICRISAT), Patancheru 502324, Andhra Pradesh, India
}

Received 6 September 2002; accepted 29 January 2003

\begin{abstract}
The overall objective of this work was to investigate variation in grain yield (GY), stover yield (SY), fodder quality of stover and their association in sorghum and pearl millet. These relationships were investigated in India in 12 genotypes of sorghum and six genotypes of pearl millet grown under high fertilizer (HF) and low fertilizer (LF) application. Fodder quality of stover was assessed by digestibility and intake measurements in bulls. In sorghum, highly significant genotype-dependent variation was found for GY, SY and fodder value of stover regardless of level of fertilizer application. GY and fodder quality of stover were not inversely related and the genotype with the highest GY, for example, had also the best fodder quality in the stover. High GY and high fodder quality in sorghum stover seem to be compatible traits. In pearl millet, genotypic variation in GY and SY and quality was expressed under HF but not under LF application. No consistent significant genotypic differences were found for fodder quality measurements in pearl millet except for cell wall digestibility. Digestible organic matter intake (DOMI) when bulls were fed to appetite was considered the crucial determinant of stover quality in sorghum and pearl millet. Live weight changes in bulls estimated by DOMI varied genotype-dependently from -140 to $+100 \mathrm{~g}$ per day in $300 \mathrm{~kg}$ bulls. However, this paper argues that genotypes promoting high DOMI are only suitable for farmers with sufficient amounts of stover to allow the feeding of animals to appetite. Farmers with restricted amounts of stover are better served by genotypes that promote high digestibility under restricted feed intake.
\end{abstract}

(C) 2003 Elsevier B.V. All rights reserved.

Keywords: Stover; Digestibility; Intake; Livestock feed; Sorghum; Pearl millet; Dual-purpose

\section{Introduction}

Cereal crop residues provide important fodder resources for ruminant animals in developing countries

\footnotetext{
* Corresponding author. Tel.: +91-40-329-6161; fax: +91-40-324-1239.

E-mail address: m.blummel@cgiar.org (M. Blümmel).
}

constituting, for example, between 41 and $66 \%$ of the available fodder in South Asia (Renard, 1997). However, the nutritive value of crop residues is commonly poor and chemical or biological techniques developed for their improvement have not been widely adopted (Chaudry, 1998). In general, too little emphasis has been given to improvement of crop residues through plant breeding and selection in the past. Several new 
crop improvement programs are now committed to improve the whole crop rather than only the grain (Reddy et al., 1995; Nordbloom et al., 1997; Rattunde, 1998; Zerbini and Thomas, 1999). This has been the result of a considerable learning process after 'improved' varieties were rejected by mixed crop-livestock farmers in West and South Asia because of poor fodder quality of the residue (Capper, 1988; Ceccareli, 1993; Kelly et al., 1996; Rattunde, 1998).

Participatory rural appraisal studies in India (Underwood et al., 2000; Rama Devi et al., 2000) have clearly shown high demand for dual-purpose sorghum and pearl millet genotypes. This demand is well founded since arable land for forage production is becoming scarce and fallow land and communal property resources available for grazing are declining. However, fodder resources can be improved without additional land requirement by introducing genotypes that provide good GY and also good fodder yield and quality in the residue (Renard, 1997). With improved fodder supply, many farmers can benefit from the increasing demand for livestock products that is forecasted to double by the year 2020 (Delgado et al., 1999). Thus, ex-ante impact analysis for dual-purpose sorghum and pearl millet genotypes has shown a cost-benefit ratio of 1-15 (Kristjianson and Zerbini, 1999).

It has been proposed that considerable potential exists for selecting and breeding of sorghum and pearl millet genotypes that have high fodder value in the residues without sacrificing GY (Reddy et al., 1995; Rattunde, 1998; Hash et al., 2000). The present work investigates 12 genotypes of sorghum and six of pearl millet grown under two management levels for: (a) genotypic variation in GY and fodder value of stover; (b) relationships between GY and fodder value; and (c) possible effects of genotypic variation in fodder value on animal performance.

\section{Material and methods}

\subsection{Genotypes of sorghum}

The following sorghum genotypes were used:

- CSH 9: A grain sorghum hybrid developed by the National Research Center for Sorghum (NRCS), Rajendranagar, Andhra Pradesh, India, using 296 A and C S 3541 as parents. It was released in 1991 for general rainy season cultivation in India. It matures in 110-115 days and grows to a height of $1.6-1.7 \mathrm{~m}$. It is a tan plant with dull green leaves with a GY of about $4.0 \mathrm{tha}^{-1}$.

- $C S V$ 15: A high yielding dual-purpose variety released in India by the Indian Sorghum Program in 1994. It is derived by pedigree selection from the cross SPV $475 \times$ SPV 462 . One of the parents, SPV 475, developed at ICRISAT, Patancheru, was released as CSV 13 in India in 1984. CSV 15 is a tan plant with thin and highly juicy stems and broad leaves with white midrib. It is a medium duration cultivar, maturing in 110-115 days and grows to a height of 2.0-2.3 m. Its panicle is semicompact and club shaped and has white, medium

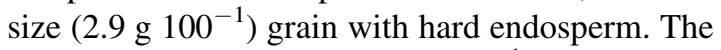
variety gives a GY of $2.9-3.1 \mathrm{t} \mathrm{ha}^{-1}$ and a fodder yield of 12.0-13.0 $\mathrm{tha}^{-1}$.

- ICSV 112: A variety bred for the rainy season and released in India as CSV 13 in 1988. It was developed by pedigree selection from a multiple cross involving IS 12622C, 555, IS 3612C, 2219B and E 35-1. Selections were made alternately at ICRISAT and Bhavanisagar, India. It matures in 110-115 days and grows about $2.2 \mathrm{~m}$ tall. It is a cream

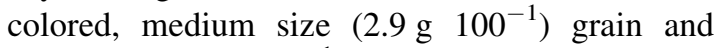
yields about $4.2 \mathrm{t} \mathrm{ha}^{-1}$. It has good fodder yield of 10.0-12.0 $\mathrm{tha}^{-1}$ and good agronomical characters. It was also released as SV 1 in Zimbabwe in 1985; as UNL-1-87 in Mexico in 1987; as Pinolero1 in Nicaragua, in 1990; as MRS 12 in Swaziland in 1992; and as Chokwe in Mozambique in 1993.

- ICSV 89057: A sweet stalk variety developed at ICRISAT involving the parents ICSV 112 and ICSV 197. It flowers in 60-70 days with a plant height of $2.0-3.0 \mathrm{~m}$. It yields $3.5-4.0 \mathrm{tha}^{-1}$ of grain.

- ICSV 93046: A sweet stalk variety developed at ICRISAT involving the parents ICSV 700 and ICSV 708. It flowers in 80-85 days with a plant height of $2.8-3.3 \mathrm{~m}$. It yields $2.5-3.0 \mathrm{tha}^{-1}$ of grain.

- Yellow local: A landrace cultivated around Patancheru, Andhra Pradesh, India. It has thin and juicy stalks and grows up to $3 \mathrm{~m}$ tall. It has short panicle with small grain and yellow pericarp. It is popular among farmers for its fodder quality. 
- CSH 16: A grain sorghum hybrid developed by NRCS, Rajendranagar, Andhra Pradesh, India, using the parents $27 \mathrm{~A}$ and C 43. It was released in 1997 for general rainy season cultivation in India. It matures in 110 days and grows to a height of $2.1 \mathrm{~m}$. It is a tan plant with dull green midrib. The panicle has good exertion with semi-compact head shape. Its GY is $4.3 \mathrm{t} \mathrm{ha}^{-1}$ and fodder yield $9.1 \mathrm{tha}^{-1}$ in All India Coordinated Sorghum trials.

- C 43: A male parent of CSH 16. It is a rainy season variety released for cultivation in India.

- HC 260: A forage cultivar.

- ICSV 745: A midge resistant variety developed at ICRISAT, Patancheru, and derived by pedigree selection from a cross between the midge resistant line ICSV 197 and A 6250, a high yielding line with good grain quality. It is a tan plant with medium-thick stems. Leaves are broad, thick and drooping in stature with white midrib. It is a medium duration cultivar maturing in 110-115 days. The variety is $2.3-2.4 \mathrm{~m}$ tall with compact panicle at the base and semi-loose at the apex. The grain is lustrous, cream colored and medium in

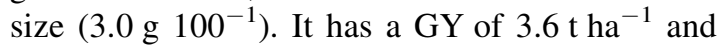
fodder yield of $8.0 \mathrm{t} \mathrm{ha}^{-1}$. As well as being extensively used as a donor for midge resistance, ICSV 745 is also resistant to rust and zonate leaf spot. It was released in Karnataka, India, as DSV-3 in 1994.

- ICSV 95132: A sweet stalk variety developed at ICRISAT with the parents IS 23392 and IS 18514. It flowers in 68-75 days. It has a plant height of 2.5-3.0 $\mathrm{m}$ and GY of 3.5-4.0 $\mathrm{t} \mathrm{ha}^{-1}$.

- Irat 204: An early, drought resistant variety released in Burkina Faso in 1980.

\subsection{Genotypes of pearl millet}

The following pearl millet genotypes were used:

- ICMV 155: A dual-purpose open-pollinated variety developed by random mating of 59 selfed progenies from the $\mathrm{C} 4$ cycle of the New Elite Composite (NELC) and released in 1991. Plants are medium tall (1.80-2.4 m), medium maturity (80-100 days), thick stemmed, many leaved, with two to four tillers. It is resistant to downy mildew. It yielded $12 \%$ more grain and $9 \%$ more fodder than
WC-C75. It has long semi-cylindrical, compact to semi-compact panicles.

- ICMV 155 bmr: A similar plant type to ICMV 155. It was produced by backcrossing the brown midrib (bmr) trait from a line received from Purdue University into the genetic background of ICMV 155 . This bmr version of ICMV 155 was developed by random mating, selected uniformly brown midribbed $\mathrm{BC}_{6} \mathrm{~F}_{4}$ progenies. The plants are distinct with brownish pigmentation of vascular bundles on both stem and leaves.

- ICMV 221: Bred by random mating 124 high yielding, drought tolerant $S_{1}$ progenies selected from the C3 cycle of the Bold Seeded Early Composite (BSEC) and released in 1993. It is an early maturing (70-80 days), thick stemmed, bold-seeded, open-pollinated variety that performs well under terminal drought conditions. Plants are $1.4-2.0 \mathrm{~m}$ tall and flower in 38-50 days. It is high yielding and resistant to downy mildew.

- ICMH 451: A dual-purpose hybrid released in 1986 from parents $81 \mathrm{~A}$ and ICMP 451. Both parents and hybrid were developed at ICRISAT, Patancheru. The plants are medium height $(1.7-2.0 \mathrm{~m})$, its flowers in 52-56 days and matures in 85-90 days. The panicles are bristled and of medium length $(25-30 \mathrm{~cm})$. It is now susceptible to prevalent strains of downy mildew but continues to exhibit slow-rusting resistance. It has high grain and fodder yields.

- ICMH 356: A hybrid released in 1993 from parents ICMA 88004 and ICMR 87003. Both parents and the hybrid were developed at ICRISAT, Patancheru. It is high yielding $\left(2.0-2.6 \mathrm{tha}^{-1}\right)$, with medium plant height $(1.6-2.0 \mathrm{~m})$, medium-early maturity (75-80 days), resistant to downy mildew.

- $N C D_{2}: \mathrm{A} \mathrm{d}_{2}$ dwarf population derived from the genetically tall Nigerian Composite (NC). NC was crossed to GAM 73, a d $\mathrm{d}_{2}$ dwarf population from Senegal with long panicles. The $\mathrm{d}_{2}$ dwarfing gene was then backcrossed into $\mathrm{NC}$ for three additional generations before 41 selected dwarf $\mathrm{BC}_{3} \mathrm{~F}_{5}$ progenies were random mated for two generations to create $\mathrm{NCD}_{2}$. Its mean $\mathrm{GY}$ is $2.86 \mathrm{tha}^{-1}$ and mean plant height $1.2 \mathrm{~m}$. The panicles are long $(30-40 \mathrm{~cm})$. The variety is early maturing taking $50-52$ days to $50 \%$ flowering. It has a high level of resistance to downy mildew. 


\subsection{Grain and stover yield}

Location, year and season of cultivation, soil type and fertilizer application were already described in Blümmel et al. (2003). The experimental layout was described in some detail by Pietzsch (1999). Briefly, grain and stover yields (SYs) were estimated from four randomly selected plots and four rows of $2 \mathrm{~m}$ length each constituting one plot of either sorghum or pearl millet but row distance was species-specific (Pietzsch, 1999). Genotypes were harvest at full maturity and total biomass was separated into heads and stover. Stover was oven-dried for approximately $36 \mathrm{~h}$ at $60{ }^{\circ} \mathrm{C}$. Heads were sun-dried for 4 days and threshed, after which dry GY was recorded.

\subsection{Animal experimental design}

The animal experimental protocol was described in Blümmel et al. (2003). Briefly, chopped stover was individually fed to $F_{1}$ crossbred (Holstein $\times$ Sahiwal) bulls with an average live weight of $262 \mathrm{~kg}$ (S.D. = 36). Each treatment (genotype $\times$ fertility) was fed to a minimum of four bulls. Bulls were accustomed to each stover for a period of 12 days followed by a period of measurements of 6 days. Feed intake was recorded daily. Faces were collected in fecal bags kept in place by belts around the girth and back of bulls.

\subsection{Calculations for estimating changes in energy status in bulls fed sorghum and pearl millet stover}

Maintenance requirements of bulls were calculated as described by McDonald et al. (1988). The metabolizable energy (ME) content of stover in megajoule (MJ) was estimated from the organic matter digestibility (OMD) measured in bulls as: gram of digestible organic matter per kilogram of stover $\times 0.016$ as suggested by AFRC (1993). For example, an OMD of 50\% is equivalent to $500 \mathrm{~g}$ of organic matter digested per kilogram of stover and its estimated ME would be $8 \mathrm{MJ} / \mathrm{kg}$ stover. The efficiency with which ME is used for maintenance requirements was derived from the metabolizability $\left(q_{\mathrm{m}}\right)$ of a stover which is defined as the ME content relative to the gross energy (GE) and $q_{\mathrm{m}}$ is equal to ME/GE. For all stovers, GE was taken to be $18.4 \mathrm{MJ} / \mathrm{kg}$ and a stover with an ME content of $8 \mathrm{MJ} / \mathrm{kg}$ has a $q_{\mathrm{m}}$ of 0.43 . According to McDonald et al. (1988) the efficiency of ME utilization for maintenance $\left(k_{\mathrm{m}}\right)$ can then be calculated as: $k_{\mathrm{m}}=0.35 q_{\mathrm{m}}+$ $0.503(=0.65)$ and a stover with $8 \mathrm{MJ} \mathrm{ME} / \mathrm{kg}$ would supply 5.23 MJ of net energy for maintenance requirements.

\subsection{Statistical analysis}

The statistic software package of SAS (1999), Version 8, with the GLM program was used for analysis of variance, comparison of means and simple correlations. The paired $t$-test was used to compare variables from $\mathrm{HF}$ and $\mathrm{LF}$ application.

\section{Results}

\subsection{Genotypic differences in GY, SY and fodder quality of stover}

\subsubsection{Sorghum}

GY and SY, OMD, organic matter intake (OMI), digestible organic matter intake (DOMI), cell wall digestibility (NDFD) and yield of digestible stover organic matter $(\mathrm{SY} \times \mathrm{OMD})$ of 12 varieties of sorghum grown under HF and LF application are reported in Table 1. Significant genotypic differences were observed for GY which was found to vary between 9.5- and 7.1-fold in HF and LF, respectively. GYs were highest in grain hybrid types of sorghum such as CSH 16 and lowest in forage-types such as ICSV 89057, ICSV 93046 and HC 260. Fertilizer application significantly $(P<0.05)$ increased GY.

Genotypic differences were also observed for SY but ranges were smaller than for GY showing 3.0- and 3.3-fold differences in HF and LF, respectively. The highest SY was observed for a forage-type ICSV 93046. On the whole, variation in SYs was not clearly associated with hybrid, dual-purpose or forage-type. Fertilizer application significantly $(P<0.05)$ increased SY.

Highly significant $(P<0.0001)$ genotype effects were found for OMI, DOMI, cell wall digestibility and yield of digestible stover per hectare. Slightly less significant effects were observed for OMD (HF: $P=0.0004$ and LF: $P=0.02$ ). The amount of stover voluntarily consumed by the animal and the 
Table 1

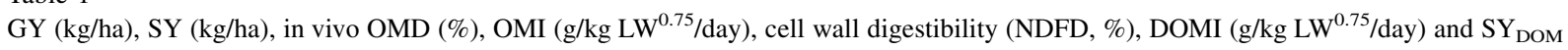
$(\mathrm{kg} / \mathrm{ha})$ of 12 varieties of sorghum stover grown under HF and LF application and their statistical summary

\begin{tabular}{|c|c|c|c|c|c|c|c|c|}
\hline & FA & GY & SY & OMD & OMI & NDFD & DOMI & $S Y_{D O M}$ \\
\hline \multicolumn{9}{|l|}{ Genotype $^{a}$} \\
\hline \multirow[t]{2}{*}{ CSH 9} & $\mathrm{HF}[\mathrm{A}]$ & 2600 & 8124 & 49.1 & 45.0 & 57.9 & 22.0 & 4033 \\
\hline & $\mathrm{LF}[\mathrm{a}]$ & 2250 & 6208 & 47.8 & 42.3 & 56.5 & 20.2 & 2967 \\
\hline \multirow[t]{2}{*}{ CSV 15} & $\mathrm{HF}[\mathrm{B}]$ & 2475 & 12790 & 48.3 & 45.3 & 49.4 & 22.0 & 6178 \\
\hline & $\mathrm{LF}[\mathrm{b}]$ & 1966 & 11915 & 45.3 & 43.5 & 49.0 & 19.6 & 5397 \\
\hline \multirow{2}{*}{ ICSV 112} & $\mathrm{HF}[\mathrm{C}]$ & 3466 & 10707 & 44.8 & 44.7 & 52.6 & 20.0 & 4798 \\
\hline & $\mathrm{LF}[\mathrm{c}]$ & 2591 & 8291 & 45.4 & 43.4 & 52.8 & 19.8 & 3764 \\
\hline \multirow[t]{2}{*}{ ICSV 9057} & $\mathrm{HF}[\mathrm{D}]$ & 1391 & 13665 & 45.1 & 43.1 & 46.6 & 19.5 & 6163 \\
\hline & $\mathrm{LF}[\mathrm{d}]$ & 558 & 9166 & 46.5 & 41.9 & 48.7 & 19.5 & 4262 \\
\hline \multirow[t]{2}{*}{ ICSV 3046} & $\mathrm{HF}[\mathrm{E}]$ & 425 & 18498 & 47.7 & 43.5 & 45.0 & 20.6 & 8824 \\
\hline & $\mathrm{LF}[\mathrm{e}]$ & 383 & 16248 & 50.7 & 41.7 & 46.5 & 21.1 & 8238 \\
\hline \multirow[t]{2}{*}{ LY } & $\mathrm{HF}[\mathrm{F}]$ & 1117 & 8832 & 48.4 & 42.9 & 53.9 & 20.8 & 4275 \\
\hline & $\mathrm{LF}[\mathrm{f}]$ & 800 & 10041 & 47.8 & 43.6 & 50.9 & 20.8 & 4800 \\
\hline \multirow[t]{2}{*}{ C 43} & $\mathrm{HF}[\mathrm{G}]$ & 2391 & 8916 & 44.9 & 52.0 & 51.8 & 23.5 & 4003 \\
\hline & $\mathrm{LF}[\mathrm{g}]$ & 1833 & 7249 & 51.6 & 44.4 & 61.9 & 23.1 & 3740 \\
\hline \multirow[t]{2}{*}{ CSH 16} & $\mathrm{HF}[\mathrm{H}]$ & 3800 & 8374 & 52.8 & 53.4 & 60.3 & 28.3 & 4421 \\
\hline & $\mathrm{LF}[\mathrm{h}]$ & 2516 & 6458 & 52.9 & 55.1 & 60.4 & 29.2 & 3416 \\
\hline \multirow[t]{2}{*}{ HC 260} & HF [I] & 692 & 6708 & 50.9 & 55.5 & 54.6 & 28.3 & 3414 \\
\hline & $\mathrm{LF}[\mathrm{I}]$ & 1066 & 6916 & 53.6 & 44.3 & 57.4 & 23.8 & 3707 \\
\hline \multirow[t]{2}{*}{ ICSV 745} & $\mathrm{HF}[\mathrm{J}]$ & 2316 & 12124 & 51.5 & 56.5 & 54.5 & 29.2 & 6244 \\
\hline & $\mathrm{LF}[\mathrm{j}]$ & 1666 & 7457 & 48.3 & 52.3 & 51.7 & 25.5 & 3606 \\
\hline \multirow[t]{2}{*}{ ICSV 5132} & $\mathrm{HF}[\mathrm{K}]$ & 1667 & 9249 & 50.3 & 48.9 & 55.9 & 24.6 & 4652 \\
\hline & $\mathrm{LF}[\mathrm{k}]$ & 1641 & 7541 & 54.6 & 50.4 & 60.7 & 27.6 & 4117 \\
\hline \multirow[t]{2}{*}{ IRAT 204} & $\mathrm{HF}[\mathrm{L}]$ & 2825 & 6083 & 56.1 & 46.1 & 64.6 & 25.9 & 3413 \\
\hline & $\mathrm{LF}[1]$ & 2250 & 4958 & 50.8 & 48.6 & 59.3 & 24.7 & 2519 \\
\hline \multicolumn{9}{|c|}{ Statistical summary ${ }^{\mathrm{b}, \mathrm{c}}$} \\
\hline Mean & $\mathrm{HF}+\mathrm{LF}$ & 1862 & 9438 & 49.0 & 46.6 & 54.0 & 23.0 & 4613 \\
\hline$P$ & & $\leq 0.0001$ & $\leq 0.0001$ & $\leq 0.0001$ & $\leq 0.0001$ & $\leq 0.0001$ & $\leq 0.0001$ & $\leq 0.0001$ \\
\hline LSD & & 440 & 1478 & 3.8 & 3.8 & 4.3 & 2.3 & 726 \\
\hline Mean & $\mathrm{HF}$ & 2097 & 10339 & 48.8 & 47.46 & 53.46 & 23.3 & 5028 \\
\hline$P$ & & $\leq 0.0001$ & $\leq 0.0001$ & $\leq 0.0004$ & $\leq 0.0001$ & $\leq 0.0001$ & $\leq 0.0001$ & $\leq 0.0001$ \\
\hline LSD & & 602 & 2824 & 4.8 & 5.2 & 5.6 & 3.1 & 1373 \\
\hline Mean & LF & 1627 & 8543 & 49.3 & 45.62 & 54.51 & 22.7 & 4197 \\
\hline$P$ & & $\leq 0.0001$ & $\leq 0.0001$ & $\leq 0.02$ & $\leq 0.0001$ & $\leq 0.0001$ & $\leq 0.0001$ & $\leq 0.0001$ \\
\hline LSD & & 656 & 1795 & 5.96 & 5.61 & 6.7 & 3.6 & 891 \\
\hline
\end{tabular}

${ }^{\mathrm{a}}$ Letters in square brackets identify genotypes in Fig. 5a and b.

${ }^{\mathrm{b}}$ Mean values are corrected for difference in number of replications.

${ }^{\mathrm{c}}$ Least significant difference $(P<0.05)$ related to differences between variety means across and within FA levels.

digestibility of the consumed stover, that is the DOMI, will strongly determine animal performance. Highest mean (across FAs) DOMI was observed in the grain hybrid CSH 16 while forage-type sorghums promoted only intermediate (HC 260) or even poor (sweet stalk varieties ICSV 89057 and ICSV 93046) DOMI. Fertilizer application did not effect $(P>0.05)$ any of the digestibility or intake measurements but yield 
Table 2

GY (kg/ha), SY (kg/ha), OMD (\%), OMI (g/kg LW ${ }^{0.75} /$ day), cell wall digestibility (NDFD, \%), DOMI (g/kg LW $\left.{ }^{075} / \mathrm{day}\right) \mathrm{SY}_{\mathrm{DOM}}(\mathrm{kg} / \mathrm{ha})$ of six varieties of millet grown under $\mathrm{HF}$ and LF application and their statistical summary

\begin{tabular}{|c|c|c|c|c|c|c|c|c|}
\hline & FA & GY & SY & OMD & OMI & NDFD & DOMI & $S Y_{\text {DOM }}$ \\
\hline \multicolumn{9}{|l|}{ Genotype $^{\mathrm{a}}$} \\
\hline \multirow[t]{2}{*}{ ICMH 356} & $\mathrm{HF}[\mathrm{M}]$ & 3541 & 3932 & 47.1 & 43.7 & 54.4 & 20.5 & 1852 \\
\hline & $\mathrm{LF}[\mathrm{m}]$ & 1432 & 2812 & 47.6 & 38.9 & 54.8 & 18.7 & 1339 \\
\hline \multirow[t]{2}{*}{ ICMH 451} & $\mathrm{HF}[\mathrm{N}]$ & 4218 & 5832 & 40.1 & 44.9 & 48.0 & 17.9 & 2339 \\
\hline & $\mathrm{LF}[\mathrm{n}]$ & 1771 & 3020 & 48.2 & 34.9 & 55.2 & 16.6 & 1471 \\
\hline \multirow[t]{2}{*}{ ICMV 155} & $\mathrm{HF}[\mathrm{O}]$ & 2864 & 6353 & 47.5 & 41.3 & 55.2 & 19.8 & 3018 \\
\hline & $\mathrm{LF}[\mathrm{o}]$ & 1641 & 4348 & 46.3 & 43.4 & 53.0 & 20.1 & 2013 \\
\hline \multirow[t]{2}{*}{ ICMV 155 BMR } & $\mathrm{HF}[\mathrm{P}]$ & 2578 & 5702 & 44.2 & 46.4 & 54.3 & 20.6 & 2520 \\
\hline & $\mathrm{LF}[\mathrm{p}]$ & 1224 & 3385 & 51.3 & 36.2 & 61.1 & 18.7 & 1757 \\
\hline \multirow[t]{2}{*}{ ICMV 221} & $\mathrm{HF}[\mathrm{Q}]$ & 2421 & 5416 & 48.1 & 49.3 & 54.2 & 23.8 & 2605 \\
\hline & LF [q] & 1641 & 3645 & 46.5 & 44.4 & 50.2 & 20.8 & 1695 \\
\hline \multirow[t]{2}{*}{ NCD 2} & $\mathrm{HF}[\mathrm{R}]$ & 2473 & 5989 & 46.2 & 44.7 & 53.9 & 20.7 & 2767 \\
\hline & $\mathrm{LF}[\mathrm{r}]$ & 1250 & 3333 & 45.3 & 37.7 & 55.0 & 17.1 & 1510 \\
\hline \multicolumn{9}{|l|}{ Statistical summary ${ }^{\mathrm{b}}$} \\
\hline Mean & $\mathrm{HF}+\mathrm{LF}$ & 2255 & 4481 & 46.3 & 42.5 & 53.8 & 19.7 & 2074 \\
\hline$P$ & & $<0.0001$ & $<0.0001$ & $<0.01$ & $<0.01$ & $<0.003$ & $<0.04$ & $<0.0001$ \\
\hline LSD & & $339^{1}$ & 595 & 3.3 & 5.3 & 3.4 & 2.7 & 277 \\
\hline Mean & $\mathrm{HF}$ & 3016 & 5537 & 45.5 & 45.1 & 53.3 & 20.6 & 2517 \\
\hline$P$ & & $<0.0001$ & $<0.0001$ & $<0.003$ & $<0.43$ & $<0.009$ & $<0.09$ & $<0.0001$ \\
\hline LSD & & 563 & 798 & 4.0 & $\mathrm{~ns}$ & 3.9 & $\mathrm{~ns}$ & 373 \\
\hline Mean & $\mathrm{LF}$ & 1493 & 3424 & 47.2 & 39.7 & 55.0 & 18.8 & 1631 \\
\hline$P$ & & $<0.064$ & $<0.04$ & $<0.41$ & $<0.08$ & $<0.03$ & $<0.28$ & $<0.054$ \\
\hline LSD & & ns & 940 & $\mathrm{~ns}$ & $\mathrm{~ns}$ & 5.9 & ns & $\mathrm{ns}$ \\
\hline
\end{tabular}

${ }^{a}$ Letters in square brackets identify genotypes in Fig. 5a and b.

${ }^{\mathrm{b}}$ Least significant difference $(P<0.05)$ related to differences between variety means across and within FA levels.

of digestible stover was higher $(P<0.05)$ in $\mathrm{HF}$ than in LF.

\subsubsection{Pearl millet}

Grain and SY, OMD, total organic matter and DOMI, cell wall digestibility and yield of digestible stover of six genotypes of pearl millet grown under HF and LF are reported in Table 2. Genotypic differences in GY were clearly $(P<0.0001)$ expressed in HF but were weakly expressed $(P=0.06)$ in LF. Highest GYs were observed for the dual-purpose variety ICMH 451 and the grain hybrid ICMH 356. Fertilizer application significantly $(P<0.05)$ increased GY.

As observed for GY, genotype-dependent differences for SY were greater $(P<0.0001)$ in $\mathrm{HF}$ than in LF $(P=0.04)$. Highest $\mathrm{SY}$ was found for the dual-purpose variety ICMV 155 but ranges in SY were smaller than those observed for sorghum. Fertilizer application significantly $(P<0.05)$ increased $\mathrm{SY}$.

Genotype differences in OMD were expressed in HF $(P=0.003)$ but not in LF $(P=0.41)$. A reverse tendency was observed for OMI where differences approached significance level in LF $(P=0.08)$ while no genotype-dependent differences were found in HF $(P=0.43)$. In contrast to OMD and OMI, significant differences were observed in cell wall digestibility of genotypes in both $\operatorname{HF}(P=0.009)$ and $\operatorname{LF}(P=0.03)$. Intake of digestible organic matter tended to differ between genotypes in HF $(P=0.09)$ but not in LF $(P=0.28)$. Yield of digestible stover was genotypedependent but this was more clearly expressed in HF $(P<0.0001)$ than in LF $(P=0.054)$ (Table 2$)$. Fertilizer application did not affect $(P>0.05)$ OMD 
and cell wall digestibility but increased significantly $(P<0.05)$ OMI and DOMI.

\subsection{Relationships between $G Y$ and $S Y$ and}

fodder quality of stover

\subsubsection{Sorghum}

Relationships between SY and GY in sorghum are presented in Fig. 1a. These two variables were not related when compared across FAs and within HF, but a significant inverse relationship was found within LF. Digestible SY and GY tended to be negatively associated and the relationship was approaching significance in across FA comparisons (Fig. 1b). However, relationships presented in Fig. 1a and b were considerably affected by one single genotype (ICSV 93046), which had highest SYs and SY DOM $_{\text {but low }}$ GYs. Omission of this genotype from the regressions
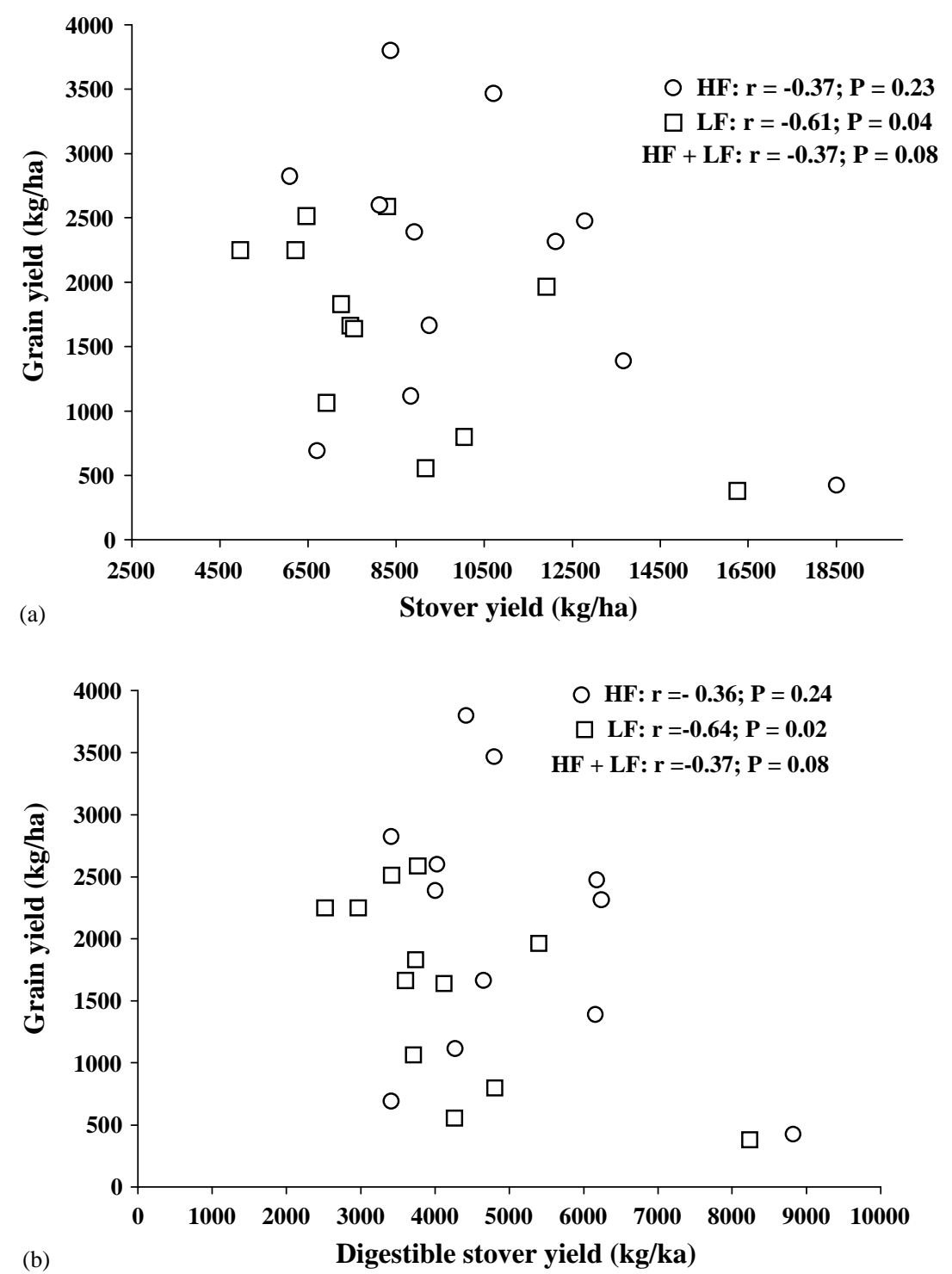

Fig. 1. (a) SY and GY in 12 varieties of sorghum grown under HF and LF level; (b) digestible SY and GY in 12 varieties of sorghum grown under HF and LF application. 


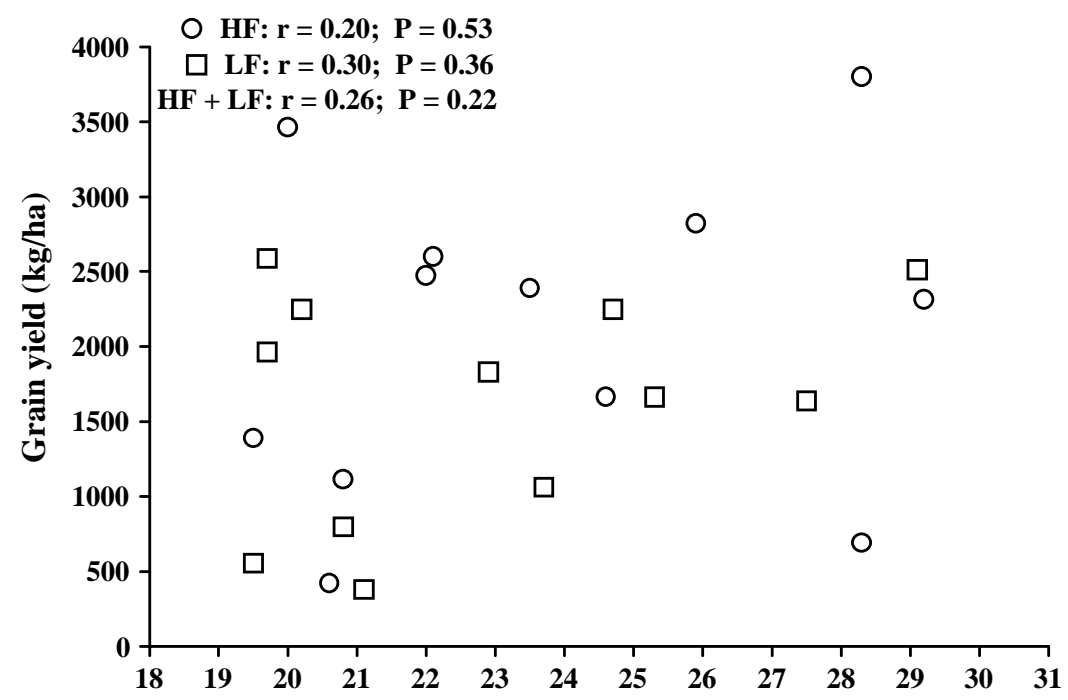

(a)

Digestible organic matter intake $\left(\mathrm{g} / \mathrm{kgLW}^{0.75}\right)$

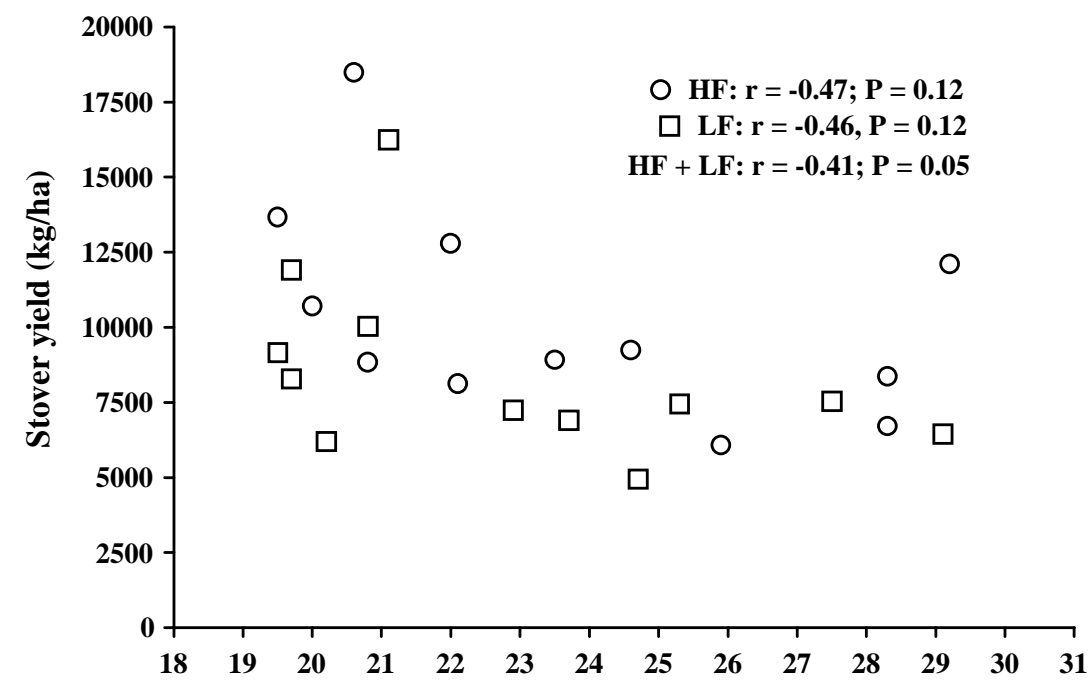

(b)

Digestible organic matter intake $\left(\mathrm{g} / \mathrm{kgLW}^{0.75}\right)$

Fig. 2. (a) Stover DOMI and GY in 12 varieties of sorghum grown under HF and LF application; (b) stover DOMI and SY in 12 varieties of sorghum grown under HF and LF application.

rendered the significant negative relationships presented in Fig. 1a and b insignificant.

The relationship between DOMI of stover as measured in bulls and grain and SYs are presented in Fig. 2. No relationship was found between DOMI and GY across and within FAs and high DOMI could be associated with very high and very low GYs. However, DOMI and SY were significantly inversely related across FAs and the relationship tended to be inverse also within FAs. This relationship was again affected by genotype ICSV 93046. After its omission from the analysis, no significant relationships were observed 

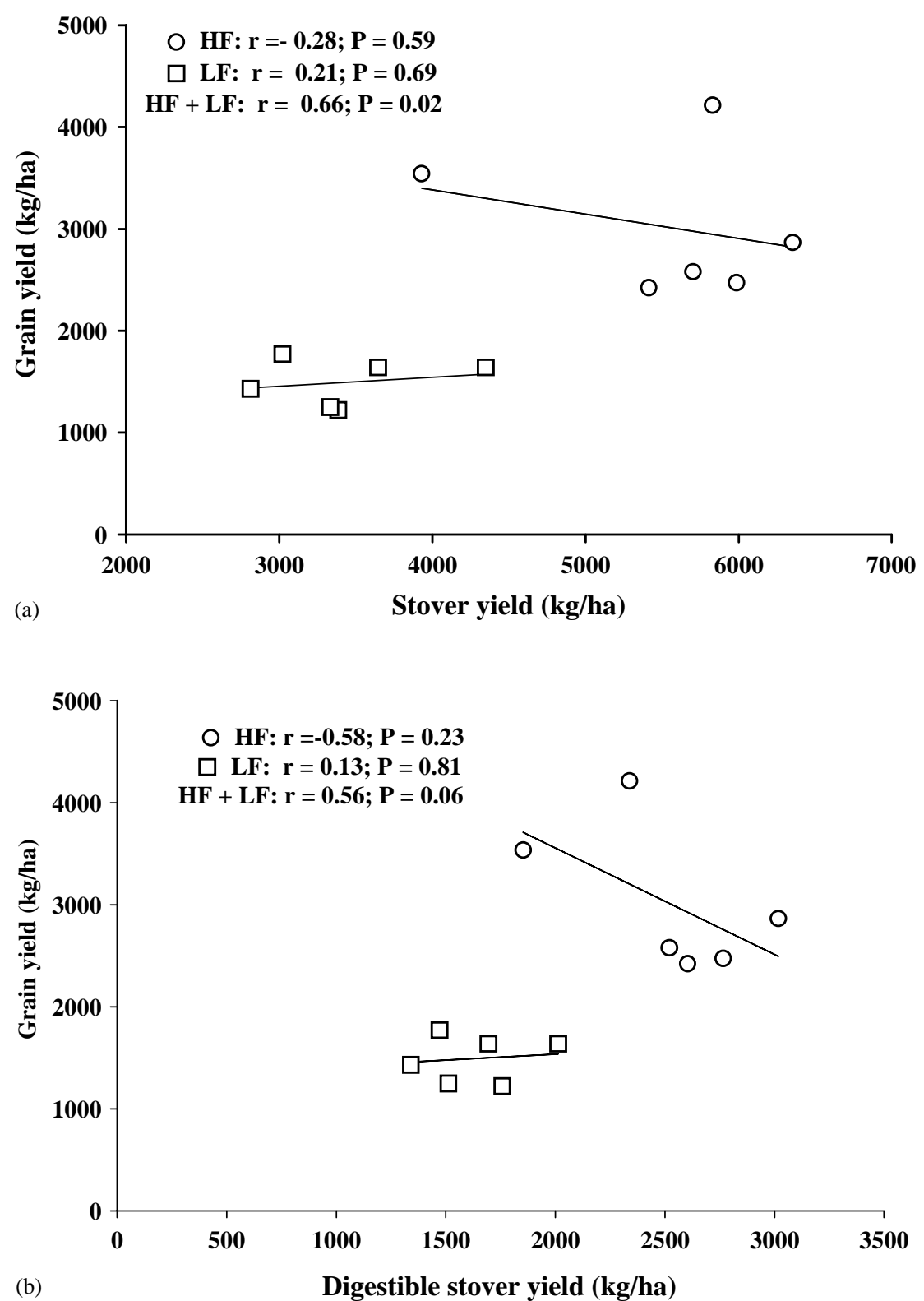

Fig. 3. SY and GY in six varieties of pearl millet grown under HF and LF level; (b) digestible SY and GY in six varieties of pearl millet grown under HF and LF level.

between DOMI and SY. However, an insignificant negative association between these two variables remained.

\subsubsection{Pearl millet}

Relationships between stover and GYs in pearl millet are presented in Fig. 3a. No significant relationship was observed between these two variables in HF and LF. The increase in grain and SYs through fertilizer application resulted in a significant positive association between these two variables when compared across FAs. Somewhat similar relationships were observed for digestible SY and GY (Fig. 3b) but negative association in HF, however, insignificant, 


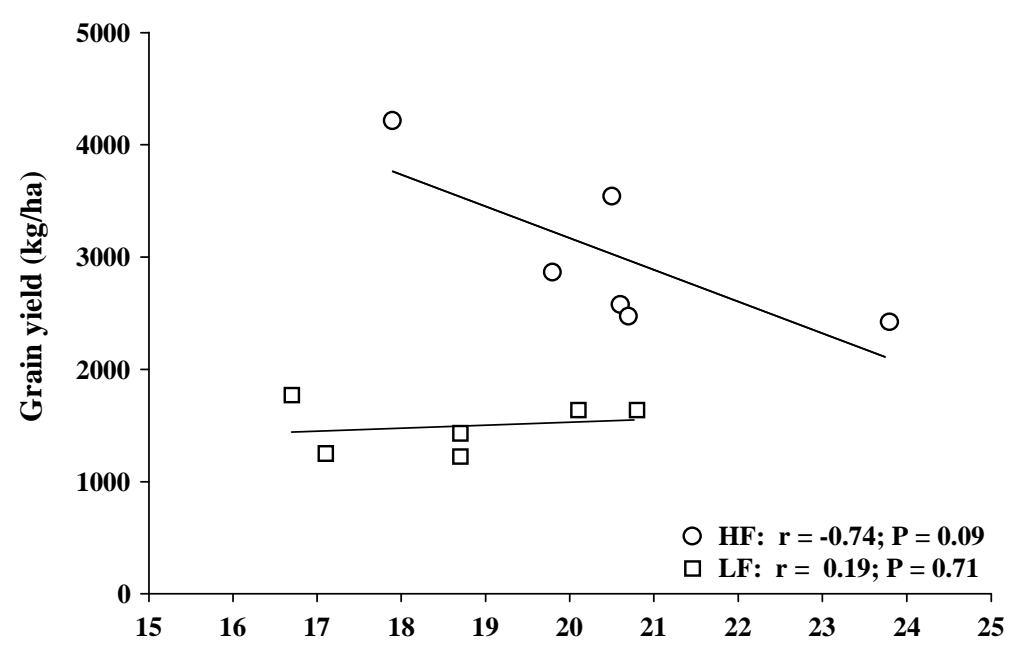

(a)

Digestible organic matter intake $\left(\mathrm{g} / \mathrm{kgLW}^{0.75}\right)$

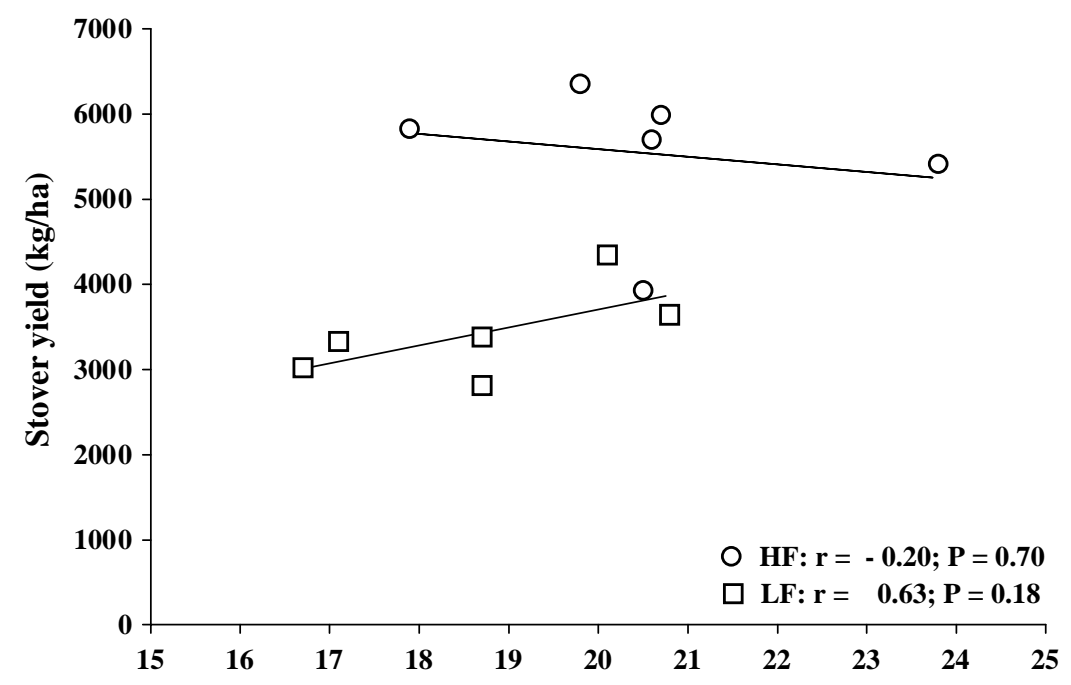

(b)

Digestible organic mater intake $\left(\mathrm{g} / \mathrm{kgLW}^{0.75}\right)$

Fig. 4. Stover DOMI and GY in six varieties of pearl millet grown under HF and LF application; (b) stover DOMI and SY in six varieties of millet grown under HF and LF application.

between total SY and digestible SY became more pronounced than observed for the relationship between stover and GY.

The relationship between DOMI of stover and GY are presented in Fig. 4. An inverse association $(P=0.09)$ was observed between DOMI and GY in HF but not in LF. DOMI of stover was not significantly related to $\mathrm{SY}$ in either HF or LF.

\section{Discussion}

\subsection{Genotypic variation in $G Y$ and $S Y$ in sorghum}

As highlighted several times in this volume, many of today's crop improvement programs are increasingly acknowledging the importance of crop residues as fodder resources and a tradable commodity in 
mixed crop-livestock systems in Asia and Africa. These programs aim at improving crop residues at source by selecting and breeding for dual-purpose genotypes that provide adequate GY and crop residues with good fodder value (Ceccareli, 1993; Reddy et al., 1995; Nordbloom et al., 1997; Rattunde, 1998; Zerbini and Thomas, 1999). This concept of genetic enhancement towards dual-purpose genotypes is subject to the following conditions: (a) genotypic variations in GY and nutritive value (the product of quantity and quality) of crop residue need to be large enough to be of practical relevance in farming situations; and (b) a high degree of independency exists between GY and fodder value of the residue because the latter should not be achieved at the expense of grain production.

With respect to the first condition, highly significant genotype-dependent variation was found for GY in sorghum across and within levels of fertilizer application. Not unexpectedly, highest GY was found for CSH 16, a grain sorghum hybrid, while low GYs were associated with forage-type sorghums like ICSV 93046 and HC 260 (Table 1). Highly significant genotype-dependent variation was also found for SY at both levels of fertilizer application with highest yields observed for forage-type sorghums. However, SY and GY tended to be inversely related, significantly $(P=0.04)$ so under LF application (Fig. 1a). When excluding the forage-type sorghum ICSV 93046 from the correlation analysis, no significant relationship was found between grain and SY. While an insignificant negative association $(P=0.24)$ between grain and SY persisted with LF application, grain and SY in sorghum appear to be traits with a considerable degree of independence (Fig. 1a). These data are in agreement with findings reported by Rattunde (1998). Non-limiting levels of available nutrients, especially nitrogen, encourage continued carbon assimilation, particularly post-physiological maturity, and thereby increase carbon allocation to non-productive vegetative growth such as basal or nodal tillers, or to stem carbohydrate storage. Such additional growth under non-limiting fertility conditions, would likely be genotype-dependent, enhancing stover mass in some genotypes, but not in others, without affecting grain mass in any. This could explain the less significant negative relationships between grain and stover productivity under high fertility conditions, than under low fertility conditions (Fig. 1a). Thus, poor management practices that limit carbon assimilation, such as LF application, might ultimately impose an inverse relationship onto these two traits at least in some genotypes (Reddy et al., 2003).

\subsection{Genotypic variation in fodder quality of sorghum stover and its association with GY and SY}

As pointed out in the preceding paper (Blümmel et al., 2003), definition of fodder value of sorghum and pearl millet stover by indirect animal performance measurements such as digestibility and voluntary feed intake only, is inconclusive unless both variables can be firmly linked to animal productivity. Although this is a complex problem for stover digestibility, digestible SY can nevertheless be regarded as a nutritionally more meaningful measurement than total SY (Blümmel et al., 2003, see also below). In the present study, an inverse relationship was observed between digestible SY and GY in sorghum under high and LF application although the relationship attained significance only in the latter (Fig. 1b).

GY and digestible SY can be inversely associated when digestibility was positively affected by residual soluble carbohydrates in the crop residue because of arrested translocation into the grain, for example in cases of stress (Goodchild et al., 1992; Van Soest, 1994). However, the relationship presented in Fig. 1b was strongly affected by the forage-type sorghum ICSV 93046. Omission of this genotype resulted in an insignificant association $(P=0.16)$ between digestible SY and GY. In general, the relationships between digestible SY and GY differed little from the relationships observed for total SY and GY (compare Fig. 1a and $b$ ) reflecting independence of stover digestibility and GY in the present work.

As shown in other papers in this volume (Blümmel et al., 2003; Coleman and Moore), statistical and conceptual evidence exists that the amount of digestible stover voluntarily consumed, that is the product of digestibility and voluntary feed intake (DOMI), should closely correlate with animal productivity. In the present study, genotype-dependent ranges in DOMI in sorghum were more than $40 \%$ of mean DOMI in both HF and LF (Table 1), which clearly suggests that choice of genotype will have considerable effect on the productivity of animals fed sorghum stover. It is encouraging, therefore, that no negative 
relationship was observed between GY and DOMI either across or within FAs (Fig. 2a). These findings show that in sorghum, genotypes can be selected that provide high fodder quality in the stover without negative effects on GY. Interestingly, CSH 16 the genotype with the highest mean (across FAs) GY and highest DOMI (Table 1) was classified by plant breeders as a grain hybrid but emerged from the present work as a very promising dual-purpose genotype. These findings underline the benefit obtained by cooperation of crop breeders and animal nutritionists in dual-purpose crop improvement programs.

While DOMI is undoubtedly a crucial determinant of fodder quality, on-farm requirements for fodder quantity may demand that DOMI should not be achieved at the expense of total SY (Renard, 1997). In the present work, DOMI tended $(P=0.12)$ to be inversely related to SY within HF and LF. This inverse relationship was significant $(P=0.05)$ in across FAs comparisons (Fig. 2b). The forage-type ICSV 93046 was not as clearly an outlier in the relationships presented in Fig. 2b as was the case in the relationships presented in Fig. 1b. Omission of ICSV 93046 from the correlations presented in Fig. $2 b$ rendered the across FAs comparison of DOMI and SY insignificant but these relationships within HF and LF tended to become more, though still insignificantly $(P<0.1)$, inverse. Work is required to further investigate the relationship between stover quality and quantity in sorghum under different management practices.

\subsection{Genotypic variation in $G Y$ and} SY in pearl millet

Highly significant $(P<0.0001)$ genotypic differences in GY and SY in pearl millet were observed under HF application but under LF application genotypic effects on GY $(P=0.06)$ and SY $(P=0.04)$ were less (Table 2). These findings suggest that improved genotypes of pearl millet will express differences in the potential for grain and SY more strongly under improved management practices. However, only six genotypes of pearl millet were included in the present study. Investigation of a wider range of genotypes may identify material that more clearly expresses genotypic differences, also under LF application.

Highest GY under HF was observed for ICMH 451, a dual-purpose pearl millet genotype, that had also above average SY (Table 2). Fertilizer application increased grain and SYs, which resulted in a positive relationship between grain and SY in across FAs comparisons (Fig. 3a). GY and SY were not significantly related either within HF or LF. However, bearing in mind that only six genotypes were investigated in the present study, ICMH 451 might be considered as a correlation breaker preventing a possible inverse relationship between stover and GY within HF. While more work is required to investigate relationships between GY, SY and their association, the results observed with ICMH 451 suggest that good GY and SY can be compatible traits in pearl millet.

\subsection{Genotypic variations in fodder quality of pearl millet stover and its association with $G Y$ and $S Y$}

Under HF application, OMD differed significantly between pearl millet genotypes within HF (Table 2). No significant difference in OMI was found in either HF or LF but genotypes tended $(P=0.08)$ to differ within the latter. The narrow genotypic variation in digestibility and intake resulted in insignificant variation in DOMI either within HF or LF, although significant tendencies $(P=0.09)$ were observed within HF (Table 2).

It is interesting to note that significant genotypic differences were found for cell wall digestibility regardless of fertilizer application (Table 2). Several authors have suggested that the cell wall digestibility of crop residues has a stronger genetic determinant than total organic digestibility, which can be influenced by residual soluble carbohydrates, and therefore, environmental effects (Goodchild et al., 1992; Van Soest, 1994). However, the relationship between cell wall digestibility measurement in pearl millet and animal productivity is unclear as yet and requires further investigation (Blümmel et al., 2003).

The possible inverse relationship between grain and SY within HF has already been discussed. Similar, but stronger, tendencies were observed for the relationship between digestible SY and GY (compare Fig. 3a and b). Inverse tendencies between stover quality indicators and grain and SY under HF application in pearl millet persisted. DOMI tended $(P=0.09)$ to be inversely associated with GY (Fig. 4a) while no such association was observed under LF application. DOMI and SY 


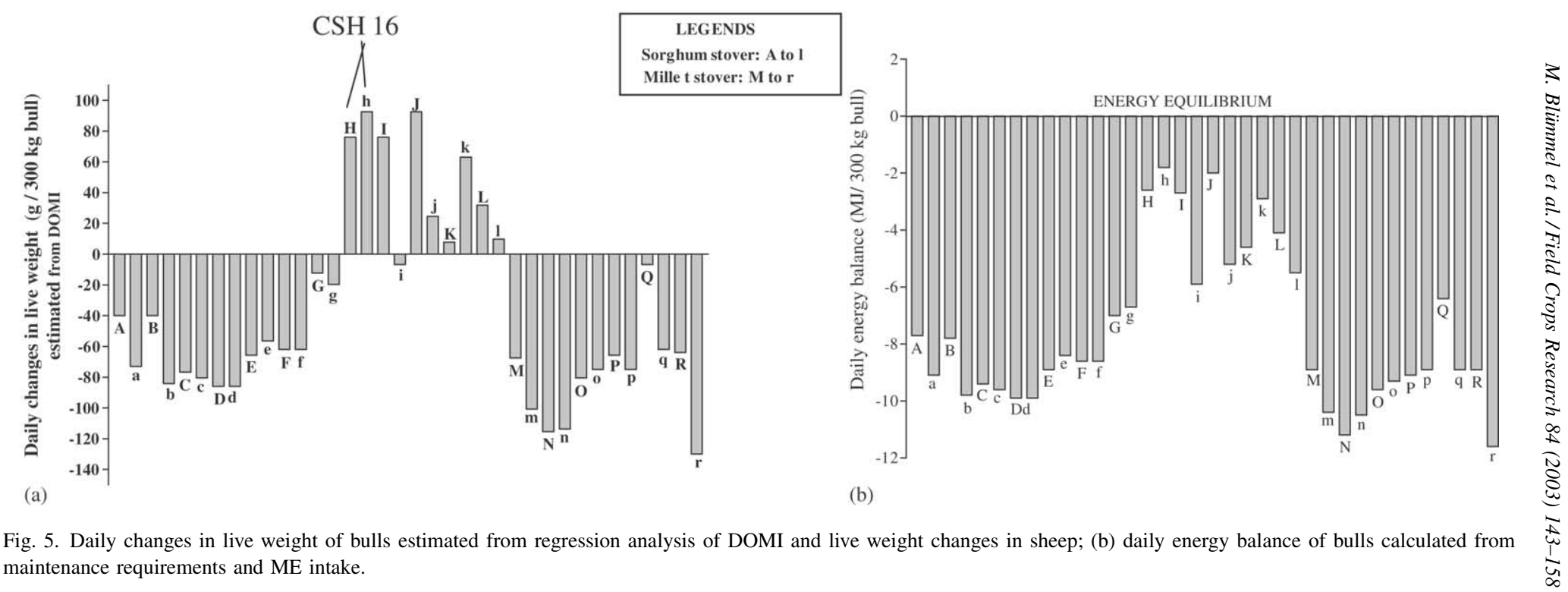


were not related under HF but a positive association appears $(P=0.18)$ to be manifest under LF.

\subsection{Possible levels of animal production from sorghum and pearl millet stover}

Currently available cereal crop residues rarely provide more than the maintenance requirement, that is, the status when no energy is lost nor gained by the animal, also known as energy equilibrium (McDonald et al., 1988). In a simplified manner, animals produce meat or milk when nutrient supply from fodder exceeds their maintenance requirement. Cereal crop residues that provide for maintenance requirements are considered superior (Renard, 1997) although it has also been shown that sheep could even moderately gain when fed unsupplemented straw from a barley landrace (Capper et al., 1989; Blümmel et al., 1998). In these experiments, live weight changes in sheep on barleys straws could be predicted by the regression equation

$y=-44.7+18.4 x \quad\left(R^{2}=0.95, P<0.0001, N=8\right)$,

where $y$ is equal to changes in live weight in g per day and $x$ equal to DOMI in $\mathrm{g} / \mathrm{kg}$ metabolic live weight per day (Blümmel et al., 2003). Applying these relationships to the DOMI of sorghum and millet stover reported in Tables 1 and 2 and relating them to a standard live weight of bulls of $300 \mathrm{~kg}$, wide ranges in calculated changes in live weight can be observed (Fig. 5a). Live weight gains were calculated for some genotypes of sorghum but not for pearl millet.

Calculations based on bio-energetic principles used in ruminant nutrition (McDonald et al., 1988; AFRC, 1993) and the OMD and OMI of the sorghum (Table 1) and pearl millet stover (Table 2) in bulls resulted in a less favorable energy balance (Fig. 5b). According to these calculations, none of the sorghum and pearl millet stovers would have supplied sufficient energy to provide for the maintenance requirement of the bulls. Following these calculations, all bulls would have been in negative energy balance, that is, they would have mobilized (and lost) body tissue to provide the energy for maintaining their essential body functions. However, these estimates based on bio-energetic principles might be too pessimistic. They were derived from European ruminant animals. They might underestimate the potential of tropical breeds on crop residue diets. On the whole, the calculations presented in Fig. 5a and b broadly agree in that they demonstrate the wide genotype-dependent ranges in animal performance for stover-fed animals.

\subsection{Dual-purpose sorghum and pearl millet genotypes in the farming system}

Participatory rural appraisal studies (Underwood et al., 2000; Rama Devi et al., 2000) and ex-ante assessments (Kristjianson and Zerbini, 1999) have underlined the importance of quality crop residues in smallholder farming systems. In a recent stakeholder workshop, farmers opted for increased stover quantity and quality even at some expense in GY. In this context it is important to realize that for sorghum in India, for example, the price ratio for grain and stover is only about 3:1 (Kelly et al., 1996) while the weight ratio of $S Y$ to $G Y$ is generally $>4: 1$. Farmers, therefore, can derive greater benefit from stover than from grain. Stover is mostly sold when in excess of on-farm feed requirements. But it is generally the case that stover is a scarce on-farm feed resource. This scarcity presents problems to stover quality assessments but identifies the need to give attention to both stover quantity and quality in dual-purpose crop improvement programs.

Accepting the hypothesis that voluntary feed intake is the most crucial single determinant of animal productivity (Crampton et al., 1960; Fahey and Hussein, 1999), particularly in crop residues (Capper et al., 1989; Blümmel et al., 1998), voluntary feed intake as a quality determinant is probably redundant when farmers cannot afford to feed animals to appetite because of shortage of stover. Thus, restricting the amount offered of a stover that was selected for high voluntary feed intake might well result in lower levels of animal productivity than obtained by offering the same restricted amount of a stover that was selected for high digestibility. It would be ideal if stover that promotes high voluntary feed intake also had high digestibility but as pointed out in the preceding paper (Blümmel et al., 2003) the relationship between digestibility and intake in sorghum and pearl millet stover is weak and very variable. Thus, selection of dual-purpose genotypes of sorghum and pearl millet needs to take account of overall on-farm fodder resources. The best-bet options will vary accordingly. 


\section{Acknowledgements}

The International Livestock Research Institute (ILRI) and the International Crop Research Institute for the Semi-Arid Tropics (ICRISAT) gratefully acknowledge the support of the Department for International Development (UK Competetive Research Facility) through the grant R7258 (Genetic Enhancement of Feed Quality and Quantity in Sorghum and Pearl Millet).

\section{References}

AFRC, 1993. Energy and Protein Requirements. An Advisory Manual Prepared by the AFRC Technical Committee on Response to Nutrients. CAB International, Wallingford, UK.

Blümmel, M., Moser, M., Goodchild, A.V., Gland, A., Becker, K., 1998. Kooperation von Tierernährern und Pflanzenzüchtern: Bilanz einer 10-jährigen Zusammenarbeit mit ICARDA (Cooperation of animal nutritionists and plant breeders: review of 10 years of cooperation with ICARDA). In: Technischer Fortschritt im Spannungsfeld von Ernährungssicherheit und Resourcenchutz. Tagungsband Hohenheim, pp. 199-204.

Blümmel, M., Zerbini, E., Reddy, B.V.S., Hash C.T., Bidinger, F., Ravi, D., 2003. Improving the production and utilization of sorghum and pearl millet as livestock feed: methodological problems and possible solutions. Field Crops Res. 84, 123142.

Capper, B.S., 1988. Genetic variation in the feeding value of cereal straws. Anim. Feed Sci. Technol. 21, 127-140.

Capper, B.S., Thomas, E.F., Riwali, S., 1989. Voluntary intake and digestibility of barley as influenced by variety and supplementation with either barley grain or cotton seed cake. Anim. Feed Sci. Technol. 26, 105-118.

Ceccareli, S., 1993. Plant breeding technologies relevant to developing countries. In: Gill, M., Owen, E., Pollot, G.E., Lawrence, T.L.J. (Eds.), Animal Production in Developing Countries. British Society of Animal Production Occasional Publications No. 16, pp. 37-55.

Chaudry, A.S., 1998. Chemical and biological procedures to upgrade cereal straws for ruminants. CAB Abstracts. Nutr. Abstr. Rev. Ser. B 68, 319-331.

Crampton, E.E., Donefer, E., Loyd, L.E., 1960. A nutritive value index of forages. J. Anim. Sci. 19, 538-544.

Delgado, C., Rosegrant, M., Steinfeld, H., Ehui, S., Courbois, C., 1999. Livestock to 2020: The Next Food Revolution. IFPRI Food, Agriculture and the Environment Discussion Paper No. 28. International Food Policy Research Institute, Food and Agriculture Organization of the United Nations, and International Livestock Research Institute, Washington, DC, 72 pp.

Fahey Jr., G.C., Hussein, H.S., 1999. Forty years of forage quality research: accomplishments and impact from an animal nutrition perspective. Crop Sci. 39, 4-12.
Goodchild, A.V., Ceccarelli, S., Grando, S., Hamblin, J., Treacher, T., Thomson, E., Rihawi, S., 1992. Breeding for straw quality. In: El-Shazly, K. (Ed.), Proceedings of the International Conference on Manipulation of Rumen Microorganisms, Alexandria, Egypt, September 20-23, 1992, pp. 317-335.

Hash, C.T., Abdu Rahman, M.D., Bhasker Raj, A.G., Zerbini, E., 2000. Molecular markers for improving nutritional quality of crop residues for ruminants. In: Spangenberg, G. (Ed.), Molecular Breeding of Forage Crops. Kluwer Academic Publishers, Dordrecht, Boston, pp. 203-219.

Kelly, T.G., Parthasarathy Rao, P., Weltzien, R.E., Purohit, M.L., 1996. Adoption of improved cultivars of pearl millet in an arid environment, straw quality and quality considerations in western Rajasthan. Exp. Agric. 32, 161-171.

Kristjianson, P.M., Zerbini, E., 1999. Genetic enhancement of sorghum and millet residues fed to ruminants. ILRI Impact Assessment Series No. 3. ILRI, Nairobi, Kenya, 44 pp.

McDonald, P., Edwards, R.A., Greenhalgh, J.F.D., 1988. Animal Nutrition, 4th ed. Longman Scientific and Technical, Essex, England.

Nordbloom, T.L., Goodchild, A.V., Shomo, F., Gintzburger, G., 1997. Dynamics of feed resources in mixed farming systems of west/central Asia-North Africa. In: Renards, C. (Ed.), Crop Residues in Sustainable Mixed Crop/Livestock Farming Systems. CAB International, Wallingford, UK, pp. 131-148.

Pietzsch, M.S., 1999. Agronomic parameters and morphological parameters and in vitro and in vivo digestibility of residues of different genotypes of sorghum and pearl millet. Training Report. ICRISAT, Patancheru, Andhra Pradesh.

Rama Devi, K., Bandyopadhyay, R., Hall, A.J., Indira, S., Pande, S., Jaiswal, P., 2000. Farmers' Perception of the Effects of Plant Diseases on the Nutritive Value of Crop Residues used for PeriUrban Dairy Production on the Deccan Plateau: Findings from Participatory Rural Appraisals. Information Bulletin No. 60. International Crop Research Institute for the Semi-Arid Tropics.

Rattunde, H.F.W., 1998. Early-maturing dual-purpose sorghums: agronomic trait variations and covariation among landraces. Plant Breed. 177, 33-36.

Reddy, B.V.S., Hash, C.T., Stenhouse, J.W., Nigam, S.N., Singh, L., Van Rheenen, H.A., 1995. Crop improvement for livestock feed at ICRISAT ASIA Centre. In: Seetharam, A., Subbaeao, A., Schiere, J.B. (Eds.), Crop Improvement and its Impact on the Feeding Value of Straw and Stovers of Grain Cereals in India. Indian Council of Agricultural Research, New Delhi, India, and Department of Tropical Animal Production Agricultural University, Wageningen, The Netherlands, pp. 85-90.

Reddy, B.V.S., Reddy, P.S., Bidinger, F., Blümmel, M., 2003. Crop management factors influencing yield and quality of crop residues. Field Crops Res. 84, 57-77.

Renard, C. (Ed.), 1997. Crop Residues in Sustainable Mixed Crop/ Livestock Farming Systems. CAB International, Wallingford, UK.

SAS (Statistical Analysis System), 1999. Release 6.03 Edition. SAS Institute, Inc., Cary, NC.

Underwood, M.P., Hall, A.J., Zerbini, E., 2000. Genetic enhancement of sorghum and millet residues fed to ruminants: farmers' 
perception of fodder quality in livelihood systems. Summary Report of PRA Case Studies in Andhra Pradesh, Gujarat, Maharashtra, Karnataka and Rajasthan states. ILRI, Nairobi, Kenya and ICRISAT, Patancheru, India, 68 pp.

Van Soest, P.J., 1994. Nutritional Ecology of the Ruminant. Comstock University Press, Ithaca, NY, 476 pp.
Zerbini, E., Thomas, D., 1999. Plant breeding strategies for improving the feed resources for ruminants. In: Singhal, K.K., Rai, S.N. (Eds.), Emerging Trends for Livestock and Poultry Feeding Beyond 2000 AD. Animal Nutrition Society of India and Indian Council of Agricultural Research, pp. 189-202. 